\title{
PEMETAAN HOTS SISWA BERDASARKAN STANDAR PISA DAN TIMSS UNTUK MENINGKATKAN MUTU PENDIDIKAN
}

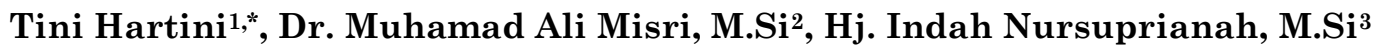 \\ ${ }^{1}$ Department of Mathemtics Education, Syekh Nurjati Islamic State University, Cirebon, Indonesia \\ ${ }^{2}$ Department of Mathemtics Education, Syekh Nurjati Islamic State University, Cirebon, Indonesia \\ ${ }^{3}$ Department of Mathemtics Education, Syekh Nurjati Islamic State University, Cirebon, Indonesia \\ *Corresponding author: tinihrt@gmail.com ${ }^{1}$, alimisri@gmail.com², indah@syekhnurjati.ac.id ${ }^{3}$
}

\begin{abstract}
The purpose of this research was to mapped the higher order thinking skills of students in solving PISA and TIMSS standards based test item based on indicators that had been compiled, as one of the effort to determine the right thing to do to increase the quality of education. The indicators in this research were the ability of analysis, evaluation, and creation. This research use a descriptive qualitative and quantitative approach. The data collection methods in this research were documentation, test, and interview. From 71 students spread across many Junior High Islamic Scoolls in Cirebon city, 2 students classified as having high order thinking skills with moderate level. Students in moderate level are found to be able to perform analysis, evaluation, and creation well in resolving some of the problems. Furthermore, 69 students are not able to perform analytical skills, evaluation, and creation well in solving all the problems, so they are considered to have low level in high order thinking skill. The difference of the student's ability due to the lack of motivation students and teachers in improving the ability of HOTS in learning. An increase in HOTS of students can be done to improve standards evaluation, improve the quality of the process and the result of learning, as well as increase the motivation students and teachers. This research can be applied to measure student's high order thinking skill in order to increase the quality of education according to international standards.
\end{abstract}

Keywords: HOTS, analysis, evaluation, creation skills

\section{PENDAHULUAN}

Pendidikan memegang peranan penting dalam memajukan suatu bangsa dan negara. Negara dikatakan maju apabila sumber daya manusianya mencukupi dan mumpuni atau dengan kata lain bermutu. sebagaimana dikatakan oleh Tjala (2016) bahwa sumber daya manusia yang bermutu merupakan faktor penting dalam pembangunan di era globalisasi saat ini. Pengalaman di banyak negara menunjukkan, sumber daya manusia yang bermutu lebih penting dari pada sumber daya alam yang melimpah.

Indonesia dengan jumlah penduduk 261,1 juta jiwa tentunya sangat mencukupi, namun sumber daya manusia juga harus mumpuni, dapat di katakan mumpuni atau bermutu apabila penduduk kita sudah mampu bersaing dengan negara lain. salah satu kunci yang dapat dilakukan untuk memajukan sumber daya manusia adalah maju di bidang pendidikan karena pendidikan adalah pupuk bagi sumber daya manusia, pendidikanlah yang dapat menentukan apakah pertumbuhan penduduk kita bermutu atau tidak (Tjalla, 2016).

Terdapat beberapa tes internasional yang digunakan selain untuk evaluasi pendidikan secara global juga digunakan untuk mengetahui apakah Indonesia sudah mampu untuk bersaing dengan negara-negara di dunia, dan dimanakah posisi Indonesia diantara negara-negara di dunia, dua diantara tes tersebut adalah Programme for International Student Asessment (PISA) dan Trends in International Mathematics and Science Study (TIMSS).

Perolehan skor literasi matematika Indonesia dalam TIMSS 2007 adalah 405 dari skor ratarata international adalah 500, dan Indonesia berada di urutan 36 dari 49 negara, dan pada tahun 2011 Indonesia memeroleh skor 386 berada di urutan 38 dari 42 negara (TIMSS, 2011). Potret pendidikan indonesia di mata dunia juga dilihat dari peringkat indonesia 
dalam PISA, PISA 2003 Indonesia berada pada peringkat ke 38 dari 40 negara untuk literasi sains dan matematika, pada tahun 2006 untuk literasi Matematika Indonesia berada pada rangking 50 dari 57 negara, pada tahun 2009 Indonesia berada pada peringkat 57 dari 65 negara dengan skor rata-rata 402 , dan pada tahun 2012 Indonesia berada pada peringkat 63 dari 64 negara dengan skor rata-rata 375 dari skor rata-rata OECD 494 (OECD, 2014).

Soal yang diujikan dalam TIMSS adalah soal pilihan ganda, dalam literasi matematika siswa tidak hanya di tuntut untuk dapat menghitung namun soal yang diberikan berupa penalaran, dan siswa diminta menuliskan alasan jawabannya sebelum memilih option (Rizta, 2013). Begitu pula soal yang diujikan dalam PISA, soal yang diujikan berupa essay dengan contoh-contoh kasus dari kehidupan sehari-hari dan siswa diminta untuk menjawabnya dari teori-teori yang mereka ketahui dalam pembelajaran dikelas (Kurniati, Harimukti, \& Jamil, 2016), menurut Wardhani dalam Kurniati (2016) dalam soal PISA siswa diminta menalar, mengevaluasi, dan mengkreasi dalam penyelesaiannya.

Rendahnya kemampuan siswa dalam pelajaran matematika disebabkan oleh kemampuan pemahaman konsep dan penalaran siswa rendah. Seperti yang dikemukakan Haqq (2016) \& (2017) bahwa salah satu faktor penyebab rendahnya kemampuan pemahaman dan penalaran matematis siswa adalah pembelajaran matematika selama ini tidak disampaikan kepada siswa secara utuh dan bersifat informatif yang berakibat pada rendahnya kedua kemampuan tersebut. Konsep-konsep pelajaran yang diberikan tidak membekas tajam dalam ingatan siswa, sehingga mudah lupa dan sering kebingungan dalam memecahkan permasalahan yang berbeda dari yang pernah dicontohkan oleh gurunya. Lebih jauh lagi, siswa tidak dapat menjawab tes, baik itu tes akhir semester maupun Ujian Nasional.

Lewy (2009) menyatakan bahwa kemampuan melibatkan analisis, evaluasi, dan kreasi dianggap sebagai kemampuan berpikir tingkat tinggi. Menurut (Brookhart, 2010) kemampuan berpikir tingkat tinggi (HOTS) meliputi kemampuan logika dan penalaran (logic and reasoning), analisis (analysis), evaluasi (evaluation), dan kreasi (creation), pemecahan masalah (problem solving), dan pengambilan keputusan (judgement). Dari apa yang dikemukakan oleh Wardhani dan Pohl di atas dapat disimpulkan bahwa PISA dan TIMSS menguji HOTS siswa, dan dari hasil tes yang diperoleh Indonesia, mencerminkan bahwa siswa Indonesia belum mencapai High Order Thingking Skill (HOTS) dan mutu pendidikan Indonesia tertinggal jauh dibanding dengan negara-negara lain.

Mutu pendidikan suatu bangsa memang tidak dapat kita tentukan hanya dengan tes internasional saja, namun dalam contoh kasus nyata di atas tidak dapat disangkal bahwa siswa Indonesia belum mencukupi standar Internasional. Untuk mengetahui apakah siswa berketerampilan berfikir tingkat tinggi maka perlu adanya pemetaan terhadap kemampuan berpikir tingkat tinggi siswa dan setelah mengetahui kemampuan siswa diharapkan dapat menjadi bahan masukan bagi peningkatan mutu pendidikan.

\section{KAJIAN PUSTAKA}

Pohl (Lewy, 2009) menyatakan bahwa kemampuan melibatkan analisis, mengevaluasi, dan mengkreasi merupakan berpikir tingkat tinggi. Sama halnya dengan Pohl, Taksonomi Anderson atau terkenal dengan taksonomi bloom yang telah direvisi membagi proses kognitif menjadi 6 tingkatan, taksonomi ini dianggap sebagai dasar dari berpikir tingkat tinggi, digambarkan sebagai berikut:

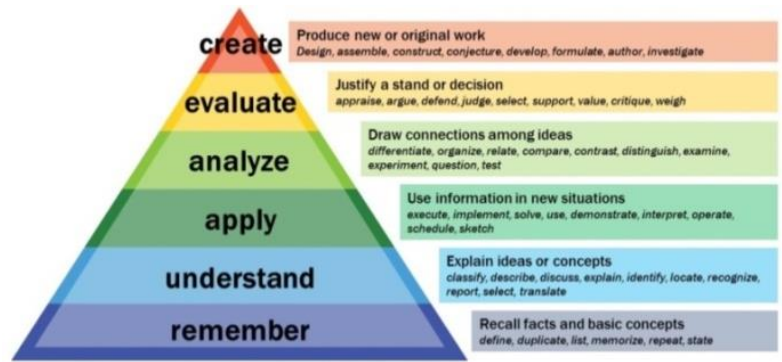

Gambar 1. Piramida Taksonomi Kognitif Anderson

Dimulai dari remember yakni level terbawah dalam berpikir, sampai dengan apply ini merupakan Low Order Thinking Skill (LOTS). High Order Thinking (HOT) yakni dimulai dari analyze hingga create. Enam tingkatan kognitif Anderson di atas dilambangkan dengan $\mathrm{C} 1, \mathrm{C} 2, \mathrm{C} 3, \mathrm{C} 4, \mathrm{C} 5$ dan $\mathrm{C} 6$ yakni creating, maka HOT berada pada level C4, C5 hingga C6. (Anderson, 2001).

Brookhart juga memperkuat pernyataan di atas menyatakan bahwa kemampuan berpikir tingkat tinggi (HOT) meliputi kemampuan logika dan penalaran (logic and reasoning), analisis (analysis), evaluasi (evalu-ation), dan 
kreasi (creation), pemecahan ma-salah (problem solving), dan pengambilan keputusan (judgement) (Brookhart, 2010). Dalam Krathwohl (2002) mengklasifikasikan bahwa pengambilan keputusan (judgement) termasuk kedalam tingkatan evaluation.

Jadi berpikir tingkat tinggi adalah kemampuan menganalisis, mengevaluasi dan mengkreasi dalam menyelesaikan permasalahan. Kemampuan analisis dapat diartikan sebagai kemampuan individu untuk menentukan bagian-bagian dari suatu masalah dan menunjukkan hubungan antarbagian tersebut, melihat penyebabpenyebab dari suatu peristiwa atau memberi argumen-argumen yang menyokong suatu pernyataan (Sudrajat, Kemampuan menganalisis dalam pembelajaran., 2011). Suherman memaparkan bahwa kemampuan evaluasi adalah kegiatan membuat penilaian berkenaan dengan nilai sebuah idea, kreasi, cara atau metode. Kemampuan kreasi adalah kemampuan untuk mengkombinasikan elemen-elemen untuk membentuk sebuah struktur yang baru dan unik, merancang cara, dan menemukan jawaban lebih dari satu (multiple solutions) (Brookhart, 2010). Penalaran merupakan suatu proses berpikir dalam menentukan sebuah kesimpulan dari suatu pengetahuan baru yang diterima dengan cara mengaitkannya dengan pengetahuan yang telah dimiliki sebelumnya (Rizta, 2013). Penalaran diperlukan dalam proses berpikir dan penarikan kesimpulan yang berupa pengetahuan.

Proses Matematika dalam matematika literasi mengarah pada tiga kata yaitu formulate (merumuskan), employ (menggunakan) dan interpret (menafsirkan). Ketiga kata ini menggambarkan proses yang harus siswa lakukan untuk menghubungkan konteks dengan matematika dan menyelesaikannya. Soal PISA 2015 meliputi salah satu dari tiga proses matematika berikut : merumuskan situasi matematika, menerapkan konsep matematika, fakta, prosedur dan bernalar serta menginterpretasikan, mengaplikasikan, dan mengevaluasi hasil matematika. Adapun kemampuan yang mendasari proses matematika ini meliputi komunikasi, matematisasi, representasi, penalaran dan argumentasi, merumuskan strategi untuk menyelesaikan masalah, menggunakan bahasa simbol, formal, dan teknik serta operasi, menggunakan alat matematika (Fauziah, 2016).
HOTs dalam PISA meliputi penalaran, analsis, evaluasi dan kreasi (Kurniati, Harimukti, \& Jamil, 2016). HOTs dalam PISA dapat dilihat dari soal dengan proses formulate (merumuskan), dimana soal dengan kata kerja merumuskan termasuk kedalam level HOTs teratas yaitu create. Untuk itu peneliti menjadikan soal dengan proses formulate ini sebagai instrumen penelitian.

Kemampuan matematika siswa dalam TIMSS sesuai benchmark internasional dibagi menjadi 4 kategori yakni sangat tinggi (advance), tinggi (high), sedang (intermediate) dan rendah (low). Dalam TIMSS dijelaskan tentang kompetensi matematika yang dicapai siswa sesuai benchmark international.

Berdasarkan domain soal-soal TIMSS terdiri dari empat konten yang diujikan yaitu konten geometry, algebra, data and chance, dan Number. Dari empat konten yang ada terdiri dari tiga domain kognitif dalam penyelesaiannya, tiga domain tersebut adalah reasoning, applying dan knowing (IEA, 2011). Berdasarkan pada domain kognitif maka applying dan knowing termasuk ke dalam LOT (Anderson, 2001), dan menurut Brookhart penalaran (reasoning) merupakan kemampuan yang terdapat pada HOT, maka HOTs dalam TIMSS yaitu penalaran dan terdapat pada soal dengan domain kognitif reasoning dalam TIMSS. Untuk itu peneliti mengadopsi soal matematika pada TIMSS domain reasoning sebagai alat ukur untuk mengatahui keterampilan HOT siswa.

\section{METODE PENELITIAN}

Jenis penelitian ini adalah penelitian deskriptif dengan pendekatan campuran (mixed methode) yaitu kualitatif dan kuantitatif. Menurut Sugiyono (2010, 2011, \& 2016) mengatakan bahwa metode penelitian kombinasi (mixed methods) adalah suatu metode penelitian yang mengkombinasikan atau menggabungkan metode penelitian kuantiatif dengan metode kualitatif untuk digunakan secara bersama-sama dalam suatu kegiatan penelitian, sehingga diperoleh data yang lebih komprehensif, valid, reliable dan obyektif.

Berdasarkan pembagian tipe penelitian mixed methods, penulis menggunakan desain tipe concurrent yang termasuk ke dalam model embedded (campuran penguatan/ metode kedua memperkuat metode pertama). Metode ini penggabungan antara metode kuantitatif dan metode kualitatif dalam satu penelitian 
dengan menggunakan gabungan pada prosedur penelitian, dimana metode yang satu lebih dominan terhadap metode yang lain (Huda, 2010).

Pada penelitian ini memetakan kemampuan berpikir tingkat tinggi (HOTS) siswa kelas VIII MTs Negeri di Kota Cirebon dengan jumlah sampel 71 responden. Pemetaannya dilakukan berdasarkan assessment analysis, evaluation, and creation dalam menyelesaikan soal PISA dan TIMSS (Anderson, 2001). Jadi, pemetaan dan pengkategorian tingkat kemamampuan berpikir tingkat tinggi merupakan sasaran utama penelitian ini. Untuk mencapai sasaran tersebut, diperlukan suatu prosedur penelitian. Adapun prosedur penelitian terdapat pada Gambar 1 berikut.

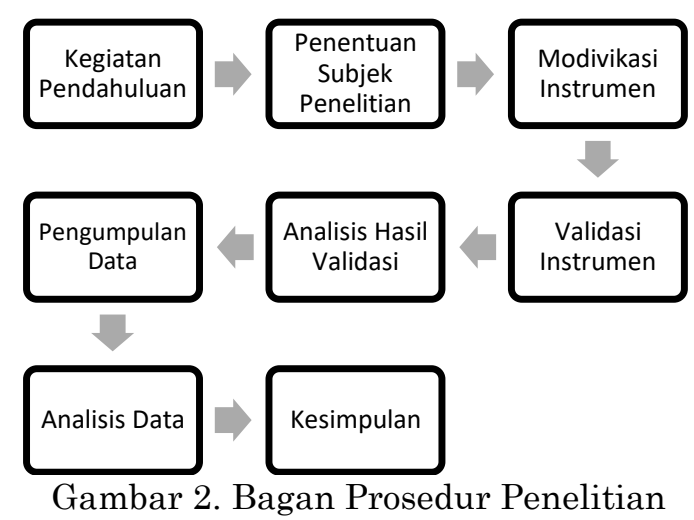

Pada bagan di atas dijelaskan bahwa tahap pertama yaitu kegiatan pendahuluan. Kegiatan pendahuluan yakni menentukan daerah/tempat penelitian yang meliputi beberapa MTs Negeri di Kota Cirebon yang terdiri dari MTs Negeri 1 dan 2 Kota Cirebon. Setelah tempat ditentukan selanjutnya yaitu menentukan subjek penelitian. Subjek penelitian ini adalah siswa kelas VIII dari MTs Negeri di Kota Cirebon.

Peneliti memilih objek penelitian yang merupakan sekolah berbasis agama dikarenakan siswa yang bersekolah pada sekolah dengan lebih banyak pembelajaran agamanya memiliki kecerdasan matematika yang lebih tinggi dibandingkan dengan siswa yang bersekolah di sekolah regular. Hal ini didukung oleh Chrisnawati (2008) yang menyebutkan bahwa keyakinan, pengetahuan, praktek dan pengalaman beragama berpengaruh pada kecerdasan emosional. Serta menurut penelitian yang dilakukan oleh Hasanah (2012) yang menyatakan bahwa siswa yang mempunyai kecerdasan emosional tinggi kemungkinan hasil prestasi belajar matematika juga baik, dan siswa yang mempunyai kecerdasan emosional sedang hasil prestasi belajar matematika siswa sedang, serta pada siswa yang mempunyai kecerdasan emosional rendah kemungkinan hasil prestasi belajar matematika rendah. Hal sejalan juga dikemukakan oleh Manfaat (2012) yang menyatakan bahwa semakin tinggi kecerdasan emosi maka semakin baik kreativitas berpikir matematika siswa.

Suatu penelitian harus ada suatu instrumen penelitian yang telah valid. Sebelum peneliti melakukan penelitian, maka peneliti harus membuat instrumen penelitian. Instrumen dalam penelitian ini terdiri dari 8 soal essay yang dimodifikasi dari soal PISA dan TIMSS, yang meliputi perubahan bahasa serta bentuk soal dari pilihan ganda ke essay (menyesuaikan dengan kebutuhan penelitian), rubrik penilaian, dan pedoman wawancara. Kemudian instrumen tersebut divalidasi kepada validator, pada penelitian ini hanya dilakukan uji validasi bahasa dan kesesuaian terjemahan dengan konten asli, serta validasi pedoman wawancara.

Jika instrumen telah valid, maka instrumen tersebut dapat digunakan untuk tahap penelitian atau pengumpulan data. Pada tahap ini dilakukan dengan melakukan tes dengan menggunakan soal berstandar PISA domain Formulate dari 4 konteks yang terdapat pada tes PISA, dan TIMSS domain Reasoning pada 4 konten yang terdapat pada soal TIMSS. Soal HOTS yang dimodivikasi dari PISA dan TIMSS yang digunakan sebagai instrumen dalam penelitian ini adalah soal dengan lingkup materi struktur bilangan, persamaan differensial, sistem persamaan dan fungsi sistem persamaan. Dasar-dasar fungsi dapat merujuk Misri (2017) sementara sisanya dapat merujuk Nursuprianah (2018). Setelah tes tersebut dilakukan, pada akhirnya dilakukan wawancara terhadap siswa untuk memperoleh data dari aspek evaluasi dan kreasi siswa.

Tahap selanjutnya adalah analisis data. pada tahap ini hasil jawaban siswa dari soal tes PISA atau TIMSS dan wawancara yang telah dilakukan akan dianalisis. Analisis ini bertujuan untuk mendeskripsikan kemampuan berpikir tingkat tinggi siswa. Setelah itu, melakukan pengkategorian level HOTS tinggi, sedang, dan rendah. Adapun langkah-langkah penglompokannya sebagai berikut. Pertama, mencari nilai minimum dengan cara mengalikan banyak soal tes dengan skor terendah rubrik penilaian untuk kemampuan HOTS. Langkah kedua, mencari 
nilai maksimum dengan cara mengalikan banyak soal tes dengan skor tertinggi rubrik penilaian setiap kemampuan HOTS. Langkah ketiga, menentukan jangkauan data tersebut. Langkah terakhir, membagi jangkauan data menjadi 3 bagian, sehingga diperoleh interval kelas. Interval kelas terendah, sedang, dan tertinggi secara berurutan mencerminkan kategori siswa HOTS level rendah, sedang, dan tinggi.

\section{HASIL DAN PEMBAHASAN}

Pengukuran tingkat kemampuan High Order Thingking Skill (HOTS) siswa dilakukan dengan pemberian test soal HOTS yang diambil dari soal yang diujikan pada PISA tahun 2012 pada domain kognitif Formulate dari masing-masing konteks yaitu Scientific, Societal, Personal, Ocupational diambil satu butir soal dan TIMSS tahun 2011 pada domain kognitif Reasoning dari masing-masing konten yaitu Number, Algebra, Geometry, dan Data and Chance diambil satu butir soal yang disesuaikan dengan kebutuhan penelitian.

Pengambilan soal HOTS dari PISA dan TIMSS didasarkan pada soal yang diujikan oleh kedua program test tersebut adalah menguji kemampuan HOTS siswa (Kurniati, 2016) seperti pada domain kognitif Formulate yang termasuk ke dalam tingkatan kognitif Create (C6) dan domain kognitif Reasoning yang termasuk ke dalam tingkatan kognitif Evaluate (C5) menurut anderson (Haladyna, 1997). Dengan demikian, hasil test HOTS tersebut mampu menjadi tolak ukur guru guna memahami dan mengetahui kemampuan HOTS siswa dan tindak lanjut pembelajaran selanjutnya.

Rendahnya hasil perolehan skor PISA dan TIMSS indonesia pada tahun 2012 lalu ternyata sejalan dengan hasil perolehan skor siswa pada penelitian ini. Hal ini bisa dilihat dari perolehan hasil test siswa, peneliti mendapat hasil rata-rata total skor siswa yakni 131,1 jauh dari skor maksimum yaitu 400. Skor rata-rata masing-masing konten yang ditunjukan dengan menggunakan bantuan Microsoft Excel 2010 yang menunjukan hasil sebagai berikut:

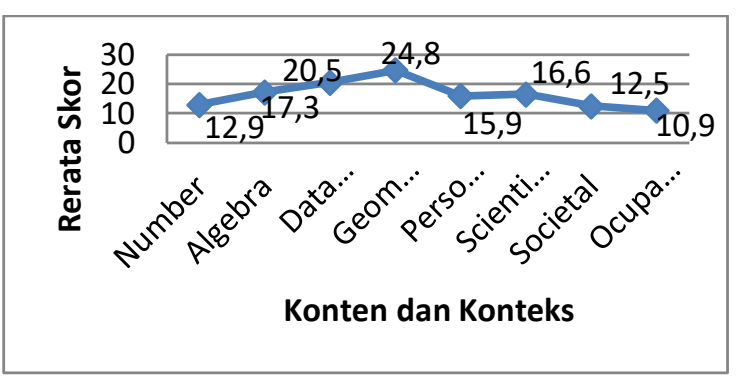

Gambar 3. Grafik Rata Rata Berdasarkan Skor Masing-Masing Konten dan Konteks

Grafik rata-rata berdasarkan skor maisngmasing konten dan konteks di atas menunjukan bahwa siswa hanya mampu mendapat skor rata-rata 13 pada konten number, rata-rata skor 17 pada konten algebra, rata-rata skor 21 pada konten data and chance, rata-rata skor 25 pada konten geometry dan konten ini adalah rata-rata perolehan skor tertinggi diantara semua konten, rata-rata skor 16 pada konteks personal, rata-rata skor 17 pada konteks scientific, rata-rata skor 13 pada konteks societal dan 11 pada konteks ocupational. Sedangkan skor maksimum dari rubrik penilaian yaitu 50 poin.

Rata-rata perolehan skor diatas berarti masih sangat jauh dari skor maksimum rubrik penilaian. Berdasarkan rubrik penilaian skor 10 adalah ketika siswa tidak mampu memahami maksud soal, jika dilihat dari ratarata nya lalu kita sesuaikan dengan rubrik penilaian maka pad number, societal, dan ocupational siswa belum mampu memahami maksud dari soal.

Pada rubrik penialaian skor 20 adalah untuk siswa yang mampu memahami maksud soal namun tidak dapat menemukan solusi secara tepat dan terdapat kesalahan pada proses penyelesian, kemudian berdasarkan rata-rata masing-masing konten di atas lalu kita sesuaikan dengan rubrik penilaian maka pada algebra, geometry, data and chance, personal dan scientific sebagian besar siswa sudah dapat memahami maksud soal namun belum mampu menyelesaiakan persoalan secara tepat.

Hal di atas juga berpengaruh terhadap hasil perolehan siswa berdasarkan domain kognitif pada soal, ditunjukan oleh Gambar 3 berikut: 


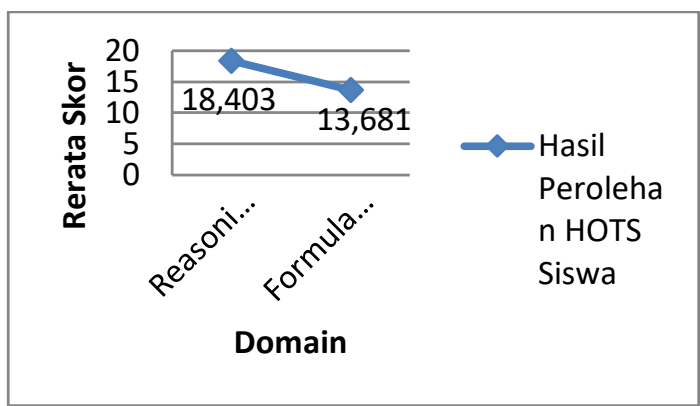

Gambar 4. Grafik Rata Rata Berdasarkan Tiap Domain Kognitif

Rata-Rata hasil perolehan test kemampuan HOTS siswa berdasarkan standar PISA dan TIMSS berdasrkan domain kognitif di atas menunjukan hasil bahwa siswa hanya mampu mancapai skor rata-rata 18 pada domain kognitif reasoning dan 14 pada domain formulate dari total skor 50, maka persentasenya yaitu pada domain kognitif reasoning siswa mampu memeroleh skor $36 \%$ dari skor maksimum rubrik penilaian dan pada domain kognitif formulate siswa hanya mampu memeroleh skor 28\% dari skor maksimum rubrik penilaian. Terdapat 71 siswa yang menjadi sampel penelitian pada penelitian ini, berdasarkan perolehan hasil test 71 siswa tersebut dipetakan ke dalam tiga kategori HOTS sebagai berikut (Kurniati, Harimukti, \& Jamil, 2016):

Tabel 1. Pemetaan Kemampuan HOTS Siswa MTsN di Kota Cirebon

\begin{tabular}{|l|l|l|}
\hline \multicolumn{1}{|c|}{ Skor } & Kategori & \multicolumn{1}{|c|}{$\sum$ Siswa } \\
\hline $80 \leq$ skor $<187$ & Rendah & 69 \\
\hline $187 \leq$ skor $<294$ & Sedang & 2 \\
\hline $294 \leq$ skor $\leq 400$ & Tinggi & 0 \\
\hline
\end{tabular}

Kategori Skor HOTS Siswa MTS Negeri Kota Cirebon menunjukan bahwa sebanyak 69 siswa berada pada kategori HOTS rendah, perolehan hasil test menunjukan nilai terendah siswa yakni 100 dan tertinggi 180 pada kategori rendah. Pada kategori HOTS sedang hanya terdapat 2 siswa, pada perolehan hasil test menunjukan bahwa nilai tertinggi siswa sebesar 200 dan posisi kedua yakni 190 . Sedangkan pada kategori HOTS tinggi belum ada siswa yang berada pada kategori ini, nilai tertinggi siswa yakni sebesar 200 hal ini berarti nilai tersebut masih jauh di bawah nilai minimum kategori HOTS tinggi. Salah satu jawaban siswa dengan HOTS level sedang sebagai berikut.

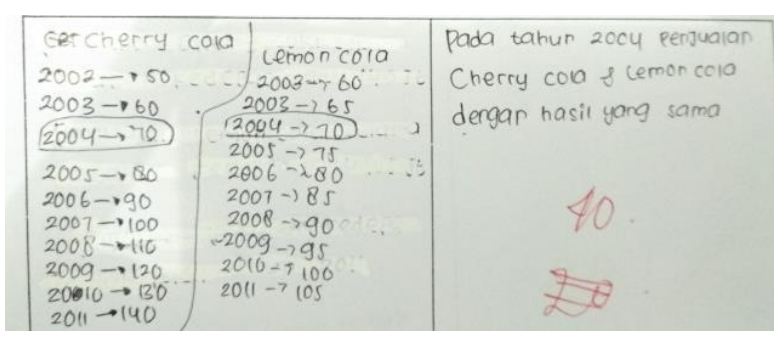

Gambar 5. Jawaban siswa kategori HOTS sedang

Jawaban siswa yang ditunjukan oleh Gambar di atas adalah benar. Siswa dapat menganalisis pola dan dapat meng-evaluate sehingga menemukan jawaban yang tepat. Namun untuk mendapat skor 50 siswa harus melibatkan proses kreasi, yakni siswa dapat membuat suatu pola dengan menggunakan materi baris dan deret, atau materi titik potong garis dengan begitu jawaban siswa akan berada pada level C6. Sedangkan siswa dengan level HOTS rendah menjawab dengan cara yang sama namun saat pengambilan kesimpulan terdapat kesalahan, berikut jawaban lembar test siswa dengan HOTS rendah.

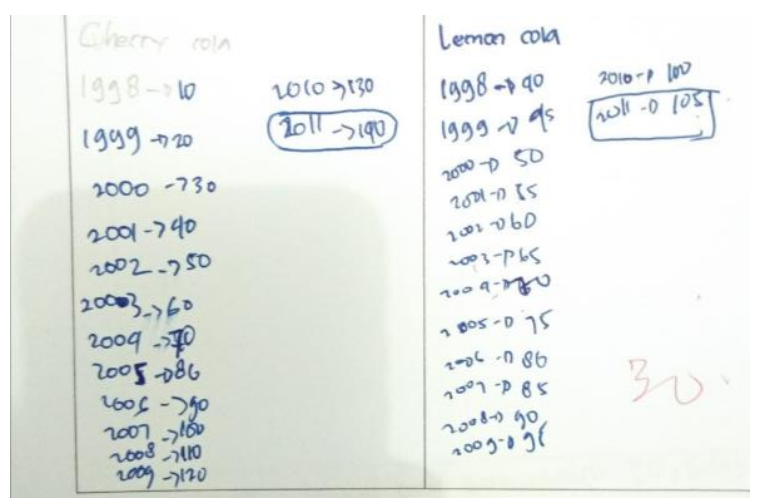

Gambar 6. Jawaban siswa kategori HOTS rendah

Jawaban di atas terlihat bahwa siswa menandai tahun 2011 yang bahkan penjualan antara lemon cola dan cherry cola tidak sama banyak. Ini membuktikan bahwa ia salah dalam mengevaluasi jawaban yang tepat atau ketidak telitian siswa dalam memahami apa yang diminta oleh soal. Siswa tersebut menuliskan alasan sebagai berikut.

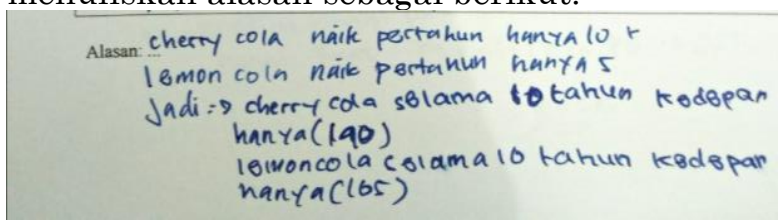

Gambar 7. Alasan jawaban siswa HOTS rendah 
Berdasarkan alasan siswa pada gambar jawaban siswa MTsN 1 Kota Cirebon pada soal konten data and chance tersebut siswa fokus pada pernyataan pada soal yang menyatakan bahwa penjualan berlangsung selama 10 tahun kedepan. Maka ia menyimpulkan bahwa yang diminta adalah penjualan pada 10 tahun kedepan tanpa memahami dengan jelas apa yang diminta pada soal, hal tersebut sejalan dengan wawancara yang dilakukan dengan informan III tersebut dengan kode W3A. Dari uraian di atas dapat diambil kesimpulan bahwa siswa MTsN 1 Kota Cirebon dalam menyelesaikan soal konten data and chance mayoritas dapat memahami dengan baik maksud soal.

Tabel 2. Pemetaan Berdasarkn Standar PISA

\begin{tabular}{|c|c|c|}
\hline $\begin{array}{l}\text { Level pada } \\
\text { PISA }\end{array}$ & Level HOTS & $\begin{array}{l}\text { Persentase } \\
\text { Siswa }\end{array}$ \\
\hline $\begin{array}{r}\text { Level } \\
6(\geq 669,3)\end{array}$ & \multirow{2}{*}{ Tinggi } & \multirow{2}{*}{$0 \%$} \\
\hline $\begin{array}{r}\text { Level } \\
5(\geqq 607,0)\end{array}$ & & \\
\hline $\begin{array}{r}\text { Level } \\
4(\geq 544,7)\end{array}$ & \multirow{2}{*}{ Sedang } & \multirow{2}{*}{$3 \%$} \\
\hline $\begin{array}{r}\text { Level } \\
3(\geq 482,7)\end{array}$ & & \\
\hline $\begin{array}{r}\text { Level } \\
2(\geq 420,1)\end{array}$ & \multirow{2}{*}{ Rendah } & \multirow{2}{*}{$97 \%$} \\
\hline $\begin{array}{r}\text { Level } \\
1(\geq 357,8)\end{array}$ & & \\
\hline
\end{tabular}

PISA memiliki level atau tingkatan tersendiri dalam penilaiannya, peneliti akan memetakan pemetaan HOTS yang ada pada penelitian ini ke dalam level atau tingkatan dalam PISA. Pemetaan tingkatan HOTS dalam penelitian ini terbagi menjadi 3 yaitu rendah, sedang, dan tinggi, sedangkan pada PISA yaitu level 1 sampai dengan level 6. Pemetaannya seperti pada Tabel 2 di atas.

Sebesar 3\% yang termasuk kedalam level sedang pada penelitian ini lebih tepatnya masuk ke dalam level 3 dalam PISA. Hal terebut di sebabkan perolehan skor siswa level sedang terebut tidak terlalu signifikan dari batas atas level rendah, dan juga siswa tersebut berkemampuan sesuai dengan deskrispsi level 3 pada PISA yang menyatakan bahwa siswa dapat memecahkan masalah namun dengan cara yang sederhana.

Hasil test kemampuan HOTS siswa berdasarkan standar PISA dan TIMSS menunjukan hasil bahwa dalam menyelesaikan soal HOTS PISA dan TIMSS siswa baru sampai pada level pemahaman (C1). Hal ini sejalan dengan kesimpulan hasil wawancara bahwa sebagian besar siswa baru sampai pada level $\mathrm{C} 1$ sampai dengan $\mathrm{C} 2$, meskipun guru telah mengusahakan memberikan soal dengan level C3 sampai dengan $\mathrm{C} 4$ dan dituntun oleh guru dalam penyelesaiannya namun tetap saja siswa belum bisa mengerjakan secara mandiri.

Hasil data yang didapat dari test kemampuan HOTS berdasarkan standar PISA dan TIMSS berupa test yang telah diberikan dan wawancara dengan orang yang dianggap memahami karakteristik siswa di sekolah menunjukan bahwa tidak semua siswa belum memiliki High Order Thinking Skill (HOTS), atau dalam penelitian ini berada pada level rendah, kemampuan siswa tersebut terpetakan kedalam HOTS sedang, serta rendah. Upaya peningkatan mutu pendidikan sekolah serta peningkatan kemampuan siswa dapat ditingkatkan dengan cara berikut.

Pertama Hasil pemetaan berdasarkan rubrik penilaian pada tiap soal menghasilkan bahwa hampir 50\% siswa tidak dapat memahami soal, hal tersebut sejalan dengan pernyataan guru matematika yang bersangkutan bahwa siswanya belum mampu mengerjakan soal tipe C4, C5 dan C6. Salah satu penyebabnya adalah kurangnya pembiasaan siswa dalam mengerjakan soal contoh kasus dengan tipe HOTS, maka dalam meningkatkan kemampuan siswa khususnya pemahaman siswa, diharapkan siswa lebih sering diberi soal contoh serta soal latihan analisis, agar kemampuan pemahaman serta pemecahan masalah siswapun bertambah, sehingga pemetaan kemampuan siswa berdasarkan domain kognitifpun dapat meningkat.

Kedua Kemampuan HOTS siswa berdasarkan standar PISA dan TIMSS dapat ditingkatkan dengan meningkatkan standar evaluasi sekolah bukan hanya dalam mata pelajaran matematika tetapi pada semua mata pelajaran. Standar evaluasi PISA dan TIMSSpun dapat diterapkan dengan strategi yang tepat secara bertahap oleh sekolah serta semua 
pelaku pendidikan harus bersinergi dengan baik.

Menurut Aziz (2015) untuk mencapai pendidikan yang bermutu yang lebih penting adalah aspek proses diantaranya proses belajar mengajar, monitoring dan evaluasi, dan aziz menggarisbawahi proses belajar mengajar merupakan kepentingan tertinggi. Proses belajar mengajar bukan hanya siswa yang menentukan keberhasilan proses tersebut, namun guru juga menjadi faktor penentu, dan tidak dapat dibandingkan mana yang lebih berpengaruh terhadap keberhasilan pembelajaran melainkan keduanya samasama sebagai penentu keberhasilan peningktan mutu pendidikan.

Rendahnya nilai siswa menurut guru sekolah masing-masing disebabkan oleh rendahnya motivasi siswa untuk belajar, serta beranggapan bahwa proses pembelajaran ditentukan oleh siswa. Meski saat ini kurikulum yang berlaku merupakan kurikululm yang berpusat pada siswa (Student Centre) namun memotivasi dan meningkatkan pengetahuan serta kemampuan siswa juga menjadi tanggung jawab guru. Maka peneliti menyimpulkan bahwa upaya peningkatan mutu pendidikan dapat dicapai dengan adanya kemauan kuat terutama dari guru dan siswa untuk maju dan meningkatkan kualitas pendidikan dengan cara meningkatkan kualitas pembelajaran (peningkatan standar evaluasi, peningkatan proses dan hasil pembelajaran, peningkatan motivasi baik siswa maupun guru), hingga siswa menjadi bermutu, selanjutnya sekolah dan berikutnya pendidikan secara keseluruhan menjadi lebih baik.

\section{Kesimpulan}

Evaluasi yang digunakan oleh guru matematika kedua sekolah MTsN 1 Kots Cirebon dan MTsN 2 Kota Cirebon menggukan soal dengan tingkatakan kognitif $\mathrm{C} 1$ sampai dengan C3, tes evaluasi yang digunakan hanya sampai pada tingkat C3 yaitu tidak termasuk ke dalam kategori HOTS. Sehingga evaluasi yang digunakan oleh kedua sekolah belum mengukur kemampuan HOTS siswa. Pengukuran tingkat kemampuan HOTS siswa dilakukan dengan pemberian test HOTS berdasarkan standar PISA dan TIMSS yang terdiri dari 4 konten yaitu number, algebra, geometry dan data and chance dan 4 koteks yaitu personal, scientific, societal dan ocupational, masing-masing diambil satu soal.
Hasil test menunjukan bahwa pemahaman peserta didik terhadap soal lebih dominan dibandingkan dengan kemampuan penyelesaian masalah pada soal. Maka hasil test tersebut memetakan siswa kedalam kategori HOTS rendah, meskipun jika dilihat dari masing-masing nilai siswa yang menunjukan terdapat siswa yang tergolong kedalam kategori HOTS sedang sebesar 3\% namun sebanyak $97 \%$ memetakan siswa MTs Negeri di Kota Cirebon kedalam kategori HOTS rendah, atau berada pada level 1 menurut standar PISA. Hal tersebut dikarenakan siswa tidak terbiasa mendapat soal dengan tipe $\mathrm{C} 4$ sampai dengan $\mathrm{C} 6$, dan kurangnya upaya peningkatan kemampuan siswa oleh guru.

Peningkatan kemampuan siswa khususnya pemahaman siswa, diharapkan siswa lebih sering diberi soal contoh serta soal latihan analisis, agar kemampuan pemahaman serta pemecahan masalah siswapun bertambah, sehingga pemetaan kemampuan siswa berdasarkan domain kognitifpun dapat meningkat. Kemudian peningkatan standar evaluasi sekolah bukan hanya dalam mata pelajaran matematika tetapi pada semua mata pelajaran. Standar evaluasi PISA dan TIMSSpun dapat diterapkan dengan strategi yang tepat secara bertahap oleh sekolah serta semua pelaku pendidikan harus bersinergi dengan baik.

Dalam proses belajar mengajar bukan hanya siswa yang menentukan keberhasilan proses tersebut, namun guru juga menjadi faktor penentu. Kedua hal tersebut tidak dapat dibandingkan mana yang lebih berpengaruh terhadap keberhasilan pembelajaran melainkan keduanya sama-sama sebagai penentu keberhasilan peningktan mutu pendidikan. Dalam penelitian ini rendahnya nilai siswa disebabkan oleh rendahnya motivasi siswa untuk belajar, serta beranggapan bahwa proses pembelajaran ditentukan oleh siswa.

Meski saat ini kurikulum yang berlaku merupakan kurikululm yang berpusat pada siswa (Student Centre) namun memotivasi dan meningkatkan pengetahuan serta kemampuan siswa juga menjadi tanggung jawab guru. Maka peneliti menyimpulkan bahwa upaya peningkatan mutu pendidikan dapat dicapai dengan adanya kemauan kuat terutama dari guru dan siswa untuk maju dan meningkatkan kualitas pendidikan dengan cara meningkatkan kualitas pembelajaran 
(peningkatan standar evaluasi, peningkatan proses dan hasil pembelajaran, peningkatan motivasi baik siswa maupun guru), hingga siswa menjadi bermutu, selanjutnya sekolah dan berikutnya pendidikan secara keseluruhan menjadi lebih baik.

Terakhir, dalam proses belajar mengajar bukan hanya siswa yang menentukan keberhasilan proses tersebut, namun guru juga menjadi faktor penentu, dan tidak dapat dibandingkan mana yang lebih berpengaruh terhadap keberhasilan pembelajaran melainkan keduanya sama-sama sebagai penentu keberhasilan peningkatan mutu pendidikan.

\section{UCAPAN TERIMA KASIH}

Terima kasih kepada reviewer jurnal EduMa: Mathematics Education Teaching and Learning atas kritik dan sarannya, terimakasih kepada pihak sekolah (MTs Negeri 1 dan MTs Negeri 2 Kota Cirebon) atas pengambilan data dalam penelitian ini, serta terimakasih kepada jurusan Tadris Matematika IAIN Syekh Nurjati Cirebon atas masukan dan bimbingan yang diberikan.

\section{DAFTAR PUSTAKA}

Anderson, L. W. (2001). A Taxonomy for learning, Teaching, and Asessing: $A$ Revision of Bloom's Taxonomy of Educational Objectives. New York: Longman.

Aziz, A. (2015). Peningkatan Mutu Pendidikan. Jurnal Studi Islam. STAI Pancawahana Bangil, 1-13.

Brookhart, S. M. (2010). How To Asses Higher Order Thinking Skills in Your Classroom. Alexandria: ASCD.

Haladyna, T. M. (1997). Writing Test Items to Evaluate Higher Order Thinkin. USA: Allyn and Bacon.

Haqq, A.A. (2016). Penerapan Challenge-based Learning dalam Upaya meningkatkan Kemampuan Pemahaman Konsep Matematis Siswa SMA. Eduma: Mathematics Educatin Learning and Teaching. Vol.5, No.2, pp. 70-76.

IEA, S. (2011). TIMSS 2011 International Results in Mathematics. Amsterdam: IEA.
Haqq, A.A. (2017). Implementasi Challengebased Learning dalam Upaya meningkatkan Kemampuan Penalaran Matematis Siswa SMA. Jurnal THEOREMS (The Original Research of Mathematics). Vol.1, No.2, pp. 13-23

Huda, A. (2010). Efektifitas Pemanfaatan Media Presentasi pada Mata Pelajaran Pendidikan Agama Islam. UIN Jakarta, 1-8.

Kurniati, D., Harimukti, R., \& Jamil, N. A. (2016). Kemampuan Berpikir Tingkat Tinggi Siswa SMP di Kabupaten Jember dalam Menyelesaikan Soal Berstandar PISA. Jurnal Penelitian dan Evaluasi Pendidikan, 20(02), 142155.

Lewy, Z. N. (2009). Pengembangan Soal untuk Mengukur Kemampuan Berpikir Tingkat Tinggi Pokok Bahasan Berisan dan Deret Bilangan di Kelas IX Akselerasi MTS Xaverius Maria Palembang. Jurnal Pendidikan Matematika, 16-26.

Manfaat, Budi, dan Kurniasih, Icih (2012). Pengaruh Emotional Quotient (Eq) Terhadap Kreativitas Berpikir Matematika Siswa (Studi Kasus Di Kelas Viii Smpn 4 Kota Cirebon). Cirebon: EDUMA

Misri, Muhamad Ali. (2017). Struktur Grup. Cirebon: CV. Confident

Nursuprianah, Indah. (2018). Mengenal Persamaan Differensial. Cirebon: IAIN Syekh Nurjati Cirebon

OECD. (2014). PISA 2012 Results in Focus What 15-year-olds know and what they can do with what they know. German: OECD Publishing

Rizta, A. d. (2013). Pengembangan Soal Penalaran Model TIMSS Matematika MTS. Jurnal pendidikan dan evaluasi pendidikan tahun 17. Palembang: Universitas Muhammadiyah Palembang(02), 1-8.

Sugiyono. (2010). Metode Penelitian Kuantitati dan Kualitatif. Bandung: Alfabeta.

Sugiyono. (2011). Metode Penelitian Pendidikan: Kuantitatif, Kualitatif dan $R \& D$. Bandung: Alfabeta. 
Sugiyono. (2016). Metode Penelitian Kombinasi (Mixed Methods). bandung: Alfabeta

TIMSS and PIRLS. (2011). TIMSS 2011 International Results in Mathematics. Amsterdam: IEA secretariat

Tjalla, A. (2016). Potret Mutu Pendidikan Indonesia Ditinjau dari Hasil-hasil Studi Internasional. Dosen FIP Universitas Negeri Jakarta, 1-22. 